\title{
O ENSINO DE MODA E A INCLUSÃO DE DEFICIENTES VISUAIS
}

Cristiani Maximiliano ${ }^{1}$

Simone Batista Tomasulo²

\begin{abstract}
RESUMO
O ensino de moda está marcado essencialmente pelo desenvolvimento de projetos de coleções, nos quais o aluno terá contato com os ciclos que os produtos percorrem entendendo o conceito da moda como a maneira de se apresentar aos outros, em relação à aparência física. É pautada pela mudança, pelo efêmero, por muitas novidades a cada nova estação, movimentando um mercado imenso, pois a roupa antes de chegar ao consumidor passa por um ciclo, que corresponde desde o beneficiamento da matéria-prima, até as passarelas e às lojas, constituindo-se como um enorme mercado, que movimenta a economia e gera empregos. Assim, este estudo objetiva analisar a possibilidade de inclusão da pessoa com deficiência visual no Curso Profissionalizante de Técnico em Produção de Moda, do Serviço Nacional de Aprendizagem Industrial (SENAI) de Blumenau, Santa Catarina, pois, entre as deficiências mais citadas nos últimos anos pelas pesquisas do Instituto Brasileiro de Geografia e Estatística (IBGE) em 2010, a visual correspondeu 18,8\% dos entrevistados. Desta forma, o ensino inclusivo visa à inserção de um indivíduo, que antes estava sendo privado em fazer parte do processo de educação, passando a fazer parte dele. Sendo assim, sugere-se como estudo nesse trabalho a inclusão de deficientes visuais no ensino de moda, através da unidade curricular Moulage. A metodologia de pesquisa adotada foi à qualitativa, exploratória, através de procedimentos bibliográficos, documentais e questionários com professores que aplicam esta técnica. O resultado mostrou-se positivo, com algumas recomendações a serem consideradas, em relação à metodologia utilizada e materiais didáticos necessários, propondo experiências práticas a fim de enriquecimento e continuidade desse estudo.
\end{abstract}

Palavras chave: Moda. Ensino. Moulage. Inclusão. Deficiência Visual.

\footnotetext{
${ }^{1}$ Especialista, e-mail: cris.mx@uol.com.br

${ }^{2}$ Mestre, e-mail: tomasulo@univali.br
} 


\section{INTRODUÇÃO}

Percebe-se que em nossa sociedade, muitas pessoas são extremamente visuais. Provavelmente, esse fato seja um dos indícios da importância dada em relação à aparência e a percepção visual que se desperta nas pessoas e que contribuiu para o aumento no mercado de beleza nos últimos anos e, no universo da moda não seria diferente, pois, é um mercado que cresce num ritmo significativo, com novas tendências, temáticas, cores, tecidos e modelagens que despertam o interesse e desejo em consumidores do mundo inteiro.

A moda possui apelo visual para aqueles que a desenvolvem e mais ainda para os que a consomem, porém, uma peça de roupa não é somente algo visual, ela pode trazer experiências sensoriais que estimulam outros sentidos, adquiridos por meio do toque que determinados tecidos proporcionam, como também o olfato que vem sendo empregado em diversos produtos e marcas. Além disso, na hora de comprar uma roupa nova, o caimento é item indispensável, pois, procura-se algo que se molde adequadamente ao corpo.

A necessidade da roupa não ser somente bela, traz a preocupação de pensar em sua ergonomia, perceber e sentir os volumes e reentrâncias do corpo humano, em analisar o toque e caimento do tecido sobre a pele, fatores relevantes que devem ser aplicados no ensino de moda, fazendo com que o aluno tenha esse cuidado ao desenvolver suas criações.

Partindo dessa concepção, surge a questão abordada e proposta nesse trabalho, de como ensinar e, consequentemente, desenvolver habilidades para pessoas com deficiências visuais nessa área. Acredita-se que por meio de técnicas e programação diferenciadas seria possível formar bons profissionais que, mesmo diante de suas deficiências, poderiam aplicar seus outros sentidos em suas criações, tornando-as exclusivas e personificadas. Assim, o aluno, e também futuro profissional, teria a oportunidade de sentir de maneira muito peculiar às formas dos corpos, as texturas de materiais, trazendo um novo conceito de produto de moda, pois seu olhar seria dado por meio de seus sentidos e, principalmente, pelo toque das suas mãos.

Desta forma, este trabalho tem como intuito abordar uma proposta de ensino técnico profissionalizante na área de moda, para deficientes visuais, considerando indivíduos que possuem a perda parcial ou total de sua capacidade visual, em caráter definitivo e que não possam melhorar ou corrigir por meio de tratamento cirúrgico, clínico ou com uso de lentes, tendo em vista sua inclusão dentro de um processo de aprendizagem voltado para atender suas necessidades diante do mercado de trabalho, a fim de proporcionar uma formação adequada e específica na área escolhida.

Segundo o IBGE (2010 apud 23,9\% Dos Brasileiros..., 2012), no Brasil, a deficiência visual foi a que mais apareceu entre as deficiências citadas, pois 18,8\% dos entrevistados, afirmaram possuir dificuldade em enxergar, mesmo com óculos ou lentes de contato, conforme o censo do Instituto Brasileiro de Geografia e Estatística. 
Portanto, pretende-se com este estudo analisar a possibilidade de inclusão da pessoa com deficiência visual no Curso Profissionalizante de Técnico em Produção de Moda, do Serviço Nacional de Aprendizagem Industrial (SENAI) de Blumenau, Santa Catarina, respondendo a seguinte questão: Como ensinar moda através da matéria de Moulage para portadores de Deficiência Visual? A proposta de ensino seria através da unidade curricular de Modelagem e Moulage (moldagem em francês), que ajusta um tecido (musselina ou morim), diretamente no manequim de tamanho apropriado ou no próprio corpo da pessoa, abordando a ideia do aluno criar e desenvolver a peça, sendo o estilista e o modelista da coleção desenvolvida.

Essa unidade curricular poderia também dividir espaços com outras, mas grande parte do ensino seria por meio da Moulage, aumentando o grau de dificuldade para cada módulo que o aluno fosse avançando, seguindo assim, uma evolução no ensino aprendizagem ao longo do curso, conforme já aplicado nos cursos existentes.

\section{CONCEITO DE MODA}

A palavra "moda" surgiu do latim modus que denomina "modo", "maneira". Ou seja, a maneira como as pessoas se apresentam aos outros, em relação à forma de vestir-se, pentear-se, comportar-se, formando uma identidade para cada indivíduo, muito além da roupa. Historicamente, pode-se observar sua importância dentro da sociedade, pois, apesar de as pessoas pertencerem a um coletivo, buscam sua diferenciação e distinção, por meio das vestimentas. Assim, a moda está presente na em nossas escolhas, nas passarelas, em revistas especializadas, nas ruas, na internet e, basicamente, em todas as áreas, tornando-se um requisito indispensável.

Por que vestir-se? Pode-se afirmar que as roupas existem por motivos de proteção das ações climáticas, quando faz frio ou calor, por pudor, vergonha de mostrar o corpo e, para os povos mais antigos, representava certa magia.

Mas se fosse somente por esses motivos, qualquer roupa já supriria as necessidades, não haveria exigências por cores, tecidos ou ornamentações específicas, no entanto, o que se tem hoje é o uso da roupa como forma de comunicar e expressar quem se é para a sociedade.

E é nessa vertente que a moda caminha, quando cria algo novo, para atender a demanda de pessoas que desejam se expressar por meio de suas roupas, traduzindo comportamentos, vontades, desejos e realizações. Conforme explica Lipovetsky (1989, p.159), "quando pensamos em moda também podemos dizer que se trata de um fenômeno temporal, caracterizado pela constante mudança, quando um lançamento faz com que o estilo anterior seja descartado.". 
Moda é um conceito que surgiu aproximadamente no século XV, na corte de Borgonha, território atualmente da França. O surgimento das Cruzadas movimento iniciado pela igreja católica para recuperar suas terras e seus cristãos teve responsabilidade de comércio entre Oriente e Ocidente Europeu. Esse movimento foi notável para o surgimento do conceito de moda, pois os cavaleiros ao voltarem do Oriente, montavam feiras nas quais comercializavam as mercadorias trazidas, sendo que foi por meio dessas vendas que surgiu uma nova classe dentro da sociedade, denominada como burgueses que, enriquecidos, buscavam satisfazer todas suas vontades, procurando referências no modo de viver dos nobres.

Em virtude desse acontecimento, os burgueses passaram a se vestir como os nobres do período. Como caracteriza Braga (2011, p. 40):

\begin{abstract}
Os nobres, não gostando muito dessa ideia, começaram a diferenciar, cada vez mais, suas roupas daquelas copiadas, criando assim um ciclo de criação e cópia. Todas as vezes que isso acontecia, ideias diferenciadas, advindas da corte, surgiam e eram colocadas em práticas vestimentárias. Aí está o conceito de moda numa acepção mais próxima da nossa realidade. Surgiu como um diferenciador social, diferenciador de sexos (tendo em vista que as roupas masculinas se encurtaram e as femininas permaneceram longas), pelo aspecto de valorização da individualidade e com o caráter de sazonalidade, ou seja, um gosto durava enquanto não era copiado, pois, se assim acontecesse, novas propostas suplantariam as, então, vigentes.
\end{abstract}

Percebe-se assim, que a moda acompanhou as etapas da história do mundo, evoluindo e retratando cada período, por meio dos cortes das roupas, seus comprimentos e detalhes, matéria prima, acabamentos e cores, funcionando como um reflexo, um autorretrato do período. Treptow (2007,p.24), afirma que "a roupa de um povo estava então, como é até hoje, diretamente relacionada às suas opções de matéria-prima e condições tecnológicas".

Dentro deste panorama, pode-se observar que o conceito de moda é pautado basicamente pela mudança, pois surgem novidades a todo o momento e, com a globalização, essas se tornaram mais acessíveis numa velocidade ainda mais rápida, pois várias pessoas ao redor do mundo têm alcance simultâneo aos novos produtos e propostas desse mercado, favorecido, principalmente, pela tecnologia da informação.

Considerando estes aspectos, observa-se que a roupa traz muito mais consigo do que a imagem que transmite, sendo algo estudado e pesquisado por muitos e muitos anos, pois os viajantes ao conhecerem novos povos, tomavam nota de como as pessoas ali presentes se adornavam e como esse vestir fazia parte do meio onde viviam, demonstrando que seus estilos de vida estavam presentes também na maneira como cobriam seus corpos.

Dessa forma, pode-se dizer que a roupa estabelece identidades coletivas de um povo, a exemplo das tribos indígenas que adornam com pinturas corporais, penas e palhas, ou então, mulheres todas cobertas com apenas o rosto ou os olhos de fora, que caracterizam as mulheres mulçumanas, conforme retratam as figuras 1 e 2 abaixo: 
Figura 1: Tribos indígenas

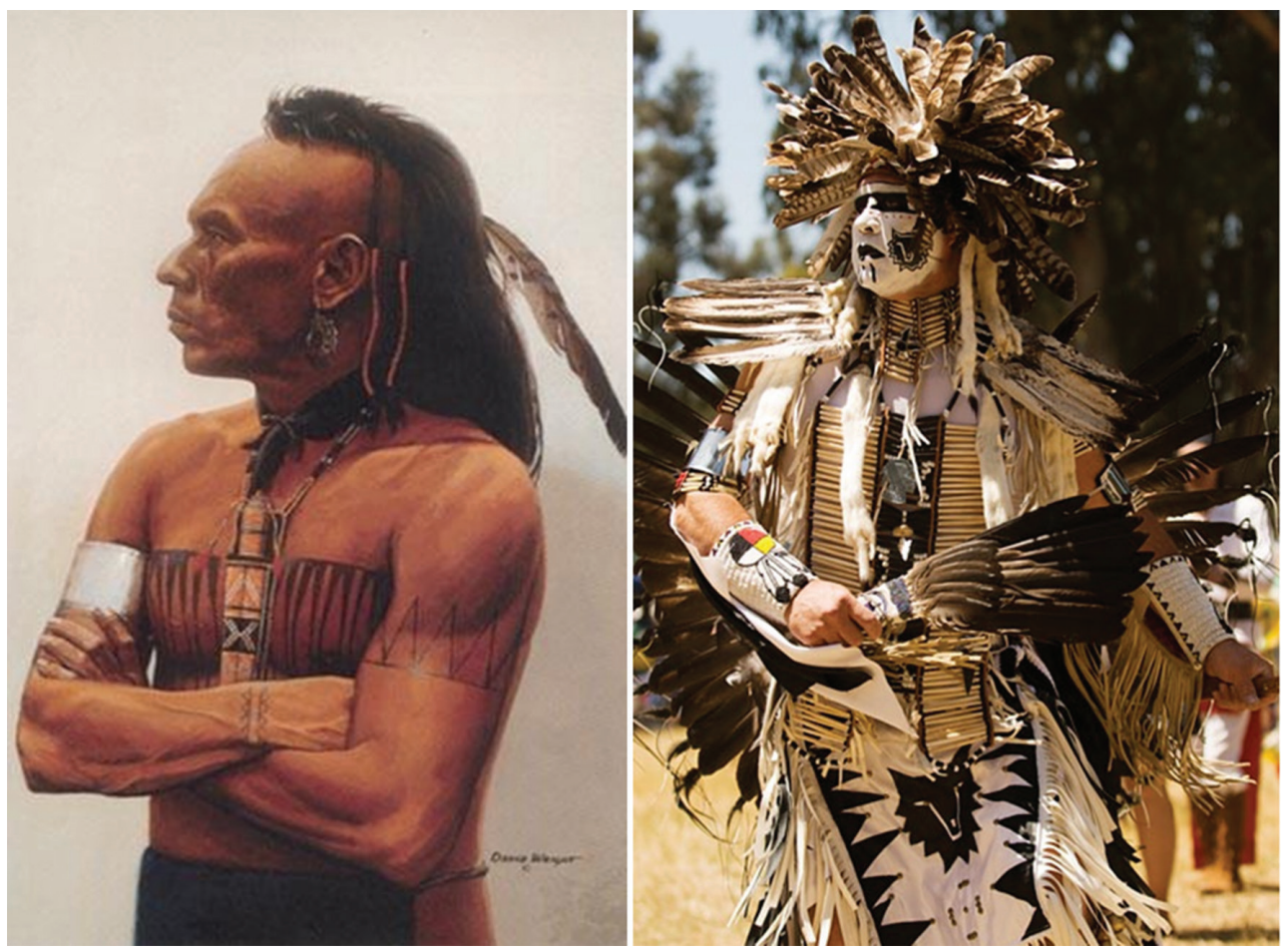

Fonte: Pinterest (2013)

Figura 2: Mulheres mulçumanas
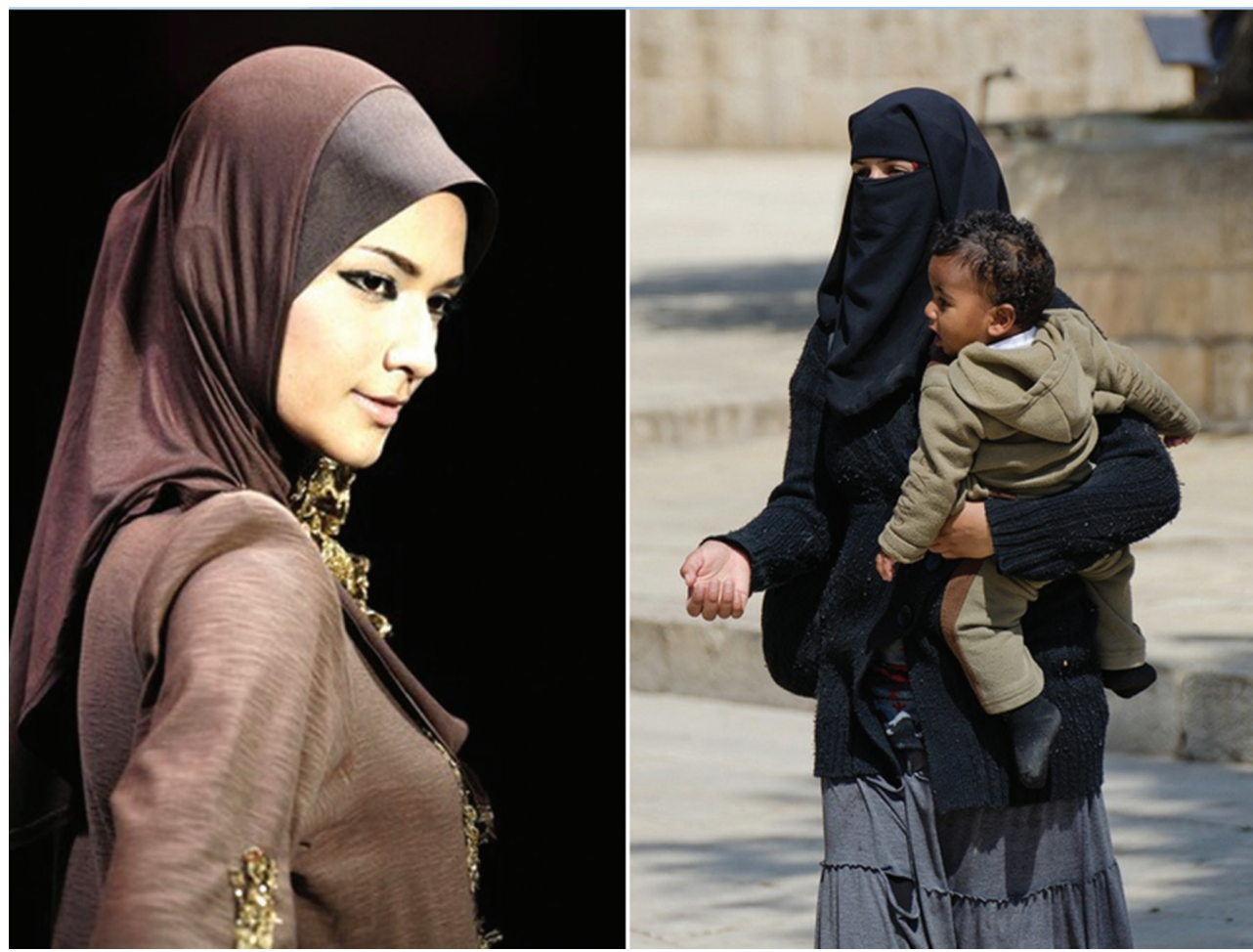

Fonte: Pinterest (2013) 
Observa-se que o uso das roupas comunica identidades coletivas, sendo que ao utilizarmos elementos semelhantes dentro de uma mesma comunidade e tempo, passamos a caracterizá-la e a identificá-la como um mesmo grupo, por outro lado, sempre existirá a vontade de se diferenciar, ser exclusivo, por meio do uso de uma cor diferente, tecidos, estampas, ou até mesmo, o corte da roupa, demonstrando que cada pessoa possui sua personalidade expressada através de suas escolhas e gosto.

Assim, a moda desempenha papel importante dentro das sociedades, ajuda a identificar períodos históricos e apontar novos e diferentes estilos de vida e perfis de consumo. Porém, muitas pessoas tratam o assunto moda como algo fútil, algo sem fundamento, ou mesmo, sobre qual a sua relação com esse universo, conclusões essas, possivelmente originadas por não conhecerem a complexidade dessa área, que além do seu glamour característico, gera empregos em diferentes mercados. Na opinião de Palomino (2003,p.18):

Há um preconceito concreto para com a moda, em parte porque o caráter da moda é de fato efêmero (ela muda oficialmente de seis em seis meses, e seu meio é a roupa) e porque ela tem a ver com a aparência (supostamente privilegiando o superficial em detrimento do intelectual: forma versus conteúdo). Muitas vezes, a moda é vista também como algo feito para iludir e enganar, para ajudar no disfarce de ser alguém que, na verdade, não se é.

Certamente, a moda hoje se trata de diferenciação, individualismo de estilo, mas também, de semelhança com os demais, pois na moda, repetições de determinadas roupas e detalhes, favorece a geração de um novo ciclo, com novos produtos e possibilidades de criação e recriação. "Deverá existir um consenso, pessoas que acreditem, concordem e consumam esta ou aquela ideia para que ela vire moda". (TREPTOW, 2007, p. 27).

É importante ressaltar também que a indústria da moda movimenta toda uma cadeia têxtil, desde a matéria prima bruta, até o produto acabado chegar às lojas e, consequentemente, na vida e uso dos consumidores, gerando empregos e movimentando as economias de muitas cidades e países.

\subsection{0 mercado de moda}

O mercado de moda está em ascensão, cada dia surge novos estilistas, marcas, estudantes a fim de criar mais produtos. Esta crescente indústria está segmentada em três gêneros: moda feminina, masculina e infantil. Na opinião de Jones (2005, p. 59):

[...] A moda feminina detém $57 \%$ da participação de mercado e é foco de $75 \%$ das empresas de estilismo. [...] A moda também muda mais rapidamente nesse setor, e o ciclo da moda pressiona mais por processos de "resposta rápida" e de "confecção just in time". A moda masculina corresponde aproximadamente $24 \%$ do mercado e está em expansão. [...] A moda masculina caracteriza-se por mudanças mais lentas nas silhuetas e escolhas de cores, pela grande atenção aos detalhes e pelo marketing por meio da logomarca e da exposição da marca ${ }^{\circ} \mathrm{A}$ moda infantil, a menor dos três, é delimitada por faixas de idade 
e tamanho. Esse mercado se volta cada vez mais para a moda casual, [...] as maiores expectativas dos pais quanto ao segmento são a segurança, a durabilidade e a versatilidade. As crianças ganham consciência da moda e das marcas cada vez mais cedo. [...] (JONES, 2005, p. 59).

Como se pode perceber os três gêneros possuem suas particularidades e almejam crescimento, por meio de marcas que atendem cada vez mais as necessidades reais de seus consumidores.

Além da segmentação por gêneros o mercado de moda está dividido em níveis de mercado, que representam os meios existentes de comercialização da moda, sendo eles:

a) Alta Costura - São coleções compostas por peças exclusivas, realizadas exatamente para o corpo da compradora, todos os detalhes e costuras são feitos manualmente. Peças vendidas para poucas afortunadas, celebridades e alta nobreza. De acordo com Renfrew e Renfrew (2010, p. 83) "estima-se que existam aproximadamente 300 mulheres em todo o mundo que podem dar-se ao luxo de comprar alta costura".

b) Prêt-à-porter - Toda coleção de moda produzida, numa escala maior e com tabelas de tamanhos estabelecidos. O público consumidor seria grande parte da população, algumas marcas de alta costura também produzem suas coleções de prêt-à-porter. Subdividindo o prêt-à-porter podemos citar as: marcas de luxo, os estilistas contemporâneos, os grandes magazines e as compras feitas em sites e catálogos de moda, sendo também subníveis do mercado de moda. Para Treptow (2007, p.38-39),

as roupas do prêt-à-porter são produzidas em escala industrial. A quantidade varia conforme o tipo de mercado para o qual a peça será distribuída. Existe o prêt-à-porter de luxo, com tiragens mínimas e limitadas por modelo e o extremo: a produção em massa para distribuição nacional ou mundial. Segundo a revista Veja (13 de junho de 2001), a rede de lojas Riachuelo produz em média 1.800 peças de cada referência para distribuir entre suas 73 lojas.

A moda passou a ser um grande negócio no mundo todo, no Brasil não seria diferente, pois atualmente, a indústria da moda brasileira reúne 30 mil empresas, movimentando cerca de R\$ 50 bilhões ao ano e empregando 1,7 milhão de pessoas, (LUCENA, 2011)

Mesmo com esses números, o mercado de moda no Brasil ainda está em fase de amadurecimento e desenvolvimento. Esse crescimento pode ser atribuído aos grandes eventos de moda realizados no país como o São Paulo Fashion Week e o Fashion Rio, eventos que acontecem há aproximadamente dezessete anos.

No ano de 2012 o Portal Fashion Forward (FFW), apresentou uma reportagem na qual mostrava que as cidades de São Paulo e Rio de Janeiro estavam entre as mais importantes da moda, sendo que o evento que acontece na capital paulista ficou em sétimo lugar no ranking e o Fashion Rio ficou com a posição de décimo sétimo, a pesquisa foi realizada pela Global Language Monitor (GLM), empresa especializada em análise de mídias, conforme observa-se no quadro 1 abaixo: 
Quadro 1: Ranking das principais capitais da moda de 2012

\begin{tabular}{|c|c|c|}
\hline Ordem & Cidade & País \\
\hline $1^{\circ}$ & Londres & Reino Unido \\
\hline $2^{\circ}$ & Nova York & Estados Unidos, \\
\hline $3^{\circ}$ & Barcelona & Espanha \\
\hline $4^{\circ}$ & Paris & França \\
\hline $5^{\circ}$ & Madri & Espanha \\
\hline $6^{\circ}$ & Roma & Itália \\
\hline $7^{\circ}$ & São Paulo & Brasil \\
\hline $8^{\circ}$ & Milão & Itália \\
\hline $9^{\circ}$ & Los Angeles & Estados Unidos \\
\hline $10^{\circ}$ & Berlim & Alemanha \\
\hline $11^{\circ}$ & Antuérpia & Bélgica \\
\hline $12^{\circ}$ & Hong Kong & China \\
\hline $13^{\circ}$ & Buenos Aires & Argentina \\
\hline $14^{\circ}$ & Bali & Indonésia \\
\hline $15^{\circ}$ & Sydney & Austrália \\
\hline $16^{\circ}$ & Florença & Itália \\
\hline $17^{\circ}$ & Rio de Janeiro & Brasil \\
\hline $18^{\circ}$ & Joanesburgo & África do Sul \\
\hline $19^{\circ}$ & Singapura & Singapura \\
\hline $20^{\circ}$ & Tóquio & Japão \\
\hline
\end{tabular}

Fonte: GLM (apud Portal Fashion Forward - FFW, [2012]) 
O Brasil possui uma posição de destaque no mercado global, pois apresenta um dos dez maiores parques têxteis do mundo, sendo também o terceiro maior produtor de malhas e o segundo maior na produção de denim (BRASIL. Ministério da cultura, [2008]). Além disso, o país é autossuficiente na produção de algodão. Referência nos segmentos jeanswear, homewear e beachwear, produzindo anualmente 9,8 bilhões de peças de vestuário. O setor têxtil é responsável por 17,5\% do Produto Interno Bruto (PIB) da indústria de transformação nacional e por cerca de $3 \%$ de todo o PIB do Brasil (DESIGN BRASIL, [2013]).

Com o crescimento do mercado e o aumento da produção, estima-se que haverá necessidade da existência de profissionais capacitados para ocupar o mercado de trabalho e atender a essa efemeridade da moda, fazendo com que muitos busquem uma formação acadêmica na área têxtil. Há dez anos, o Brasil tinha apenas vinte e quatro cursos de nível superior na área de moda, hoje tem seis vezes isso. Barros ([2012]), por meio do portal G1, ressalta que em 2002, menos de quinhentos estudantes em faculdades de moda receberam diploma no ramo, já em 2010, foram mais de três mil.

Nota-se, portanto, que realmente a moda vem ultrapassando barreiras e crescendo a cada dia, gerando novos empregos e, assim novas instituições de ensino estão oferecendo cursos na área, pois o mercado tem necessidade de inovações constantes, devido ao que temos hoje se tornar obsoleto de forma mais rápida. Na opinião de Cobra (2007, p.23):

A moda gera empregos, porque é uma indústria, e, como tal, obriga à renovação, ao consumo e, portanto, à circulação de dinheiro. Quando um consumidor compra um terno, por exemplo, está movimentando a economia e atingindo um grande número de pessoas, desde o estilista até a faxineira da loja em que comprou a roupa.

Percebe-se que com uma visão de negócio o mercado de moda, vem atingindo e alcançando destaque no país, movimentando um número significativo de pessoas e gerando várias oportunidades de empregos. Assim, o ensino de moda para deficientes visuais valoriza e soma ainda mais com a proposta apresentada no desenvolvimento desse trabalho.

\subsection{0 ensino de moda}

O ensino de moda acontece por meio da elaboração de projetos de coleções de moda, que abrangem diversas etapas e tarefas como: pesquisas de tendências, comportamentos de mercado e consumidores, criações e desenvolvimento de alternativas criativas e originais, conhecimento de práticas mercadológicas e atividades manuais. Propicia uma exploração do potencial criativo do aluno, tendo em vista que o mesmo consiga desenvolver produtos inovadores, agradáveis aos olhos e que tenham qualidade. 
Essas etapas devem ser aplicadas e desenvolvidas ao longo do curso de maneira interdisciplinar, na qual as unidades curriculares e professores possuam uma mesma linha de exigência e aplicabilidade do assunto durante o semestre, pretendendo como resultado, que o aluno adquira compreensão do ciclo que o produto de moda percorre, desde a sua concepção até chegar ao mercado.

Torna-se importante também, que durante um curso de moda, o aluno desenvolva: habilidades manuais, aumento na imaginação e originalidade em explorar técnicas, conhecimento perante os materiais utilizados na área têxtil, concepção de imagens e cores, como também consiga transmitir suas experiências pessoais para os produtos desenvolvidos, criando assim, uma identidade para suas criações.

Com a finalidade de colocar essas fases e atividades citadas em prática, são realizados trabalhos individuais ou em equipes, nos quais o aluno é testado no desempenho de seu potencial criativo e intelectual, interesses e aspirações particulares dentro dos parâmetros propostos de cada trabalho.

Esse desempenho vai ser refletido no mercado de trabalho, por meio das experiências e atividades adquiridas dentro das instituições de ensino, que deverão resultar profissionais capazes e preparados para desenvolver todo o processo que compreende uma coleção de moda ${ }^{\circ}$ Como caracteriza Renfrew e Renfrew (2010, p.7):

\footnotetext{
Todos os estilistas passam pelo mesmo processo ao desenvolver uma coleção. Tanto para aqueles que têm sua própria marca quanto para aqueles que trabalham em uma grande empresa, o ponto de partida e as etapas seguidas são invariavelmente iguais: pesquisa, criação, desenvolvimento, edição e apresentação.
}

Toma-se como exemplo, e posteriormente análise, o conteúdo programático do Curso Técnico em Produção de Moda, oferecido pela instituição de ensino SENAI/SC, na cidade de Blumenau. As unidades curriculares que correspondem a esse curso estão divididas por módulos e seguem apresentadas nos quadros 2 e 3 abaixo: 
Quadros 2 e 3: Módulos SENAI/SC

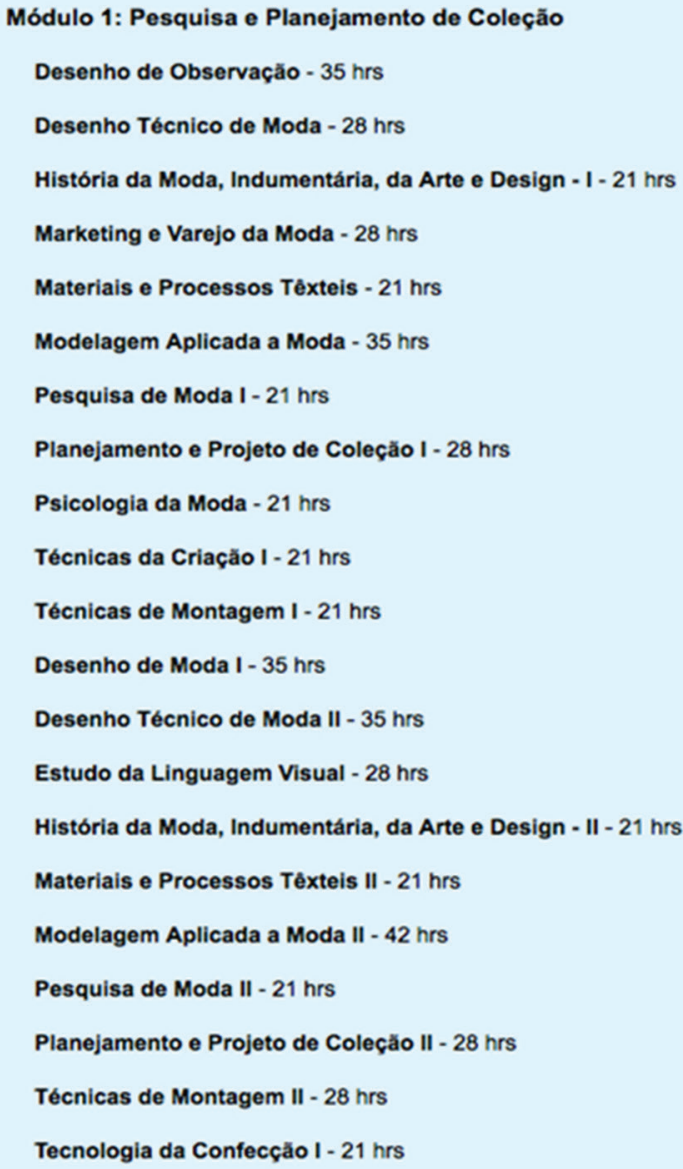



Fonte: Serviço Nacional de Aprendizagem Industrial (2013)

Esses módulos são divididos em quatro semestres, nos quais os alunos têm, desde o início de seus estudos, contato com o planejamento e desenvolvimento de um projeto de coleção de moda, sendo que o nível de cobrança em relação à sua produção vai evoluindo conforme os estudos avançam, e para o qual, a cada semestre, um novo desafio é lançado.

Nesse curso há a escolha de um gênero específico para cada projeto desenvolvido, ou seja, cada um tem seu público-alvo definido dentro do mercado de moda, sendo no primeiro semestre o público infantil, no segundo o masculino, terceiro feminino e quarto semestre o aluno está livre para escolher qual público acha mais conveniente. O desenvolvimento desses projetos ocorre de forma ordenada no qual o grau de dificuldade se estabelece pela diferenciação das modalidades apresentadas, como por exemplo: 10 semestre com temas direcionados num foco de compreensão de acordo com o grau de aprendizagem; esse grau vai evoluindo de modo que ao chegar no 4 은 semestre, o aluno deverá ser capaz de desenvolver suas pesquisas, escolher temática e 
demais pormenores de uma coleção de moda, para o qual o professor apenas ajudará com direcionamento do projeto proposto pelo próprio aluno.

Seguindo o Perfil Profissional do Curso disponibilizado pelo Serviço Nacional de Aprendizagem Industrial (2008), o aluno desenvolverá as seguintes competências consideradas gerais: pesquisar tendências de moda e de mercado, criar e desenhar esboços, acompanhar o processo de produção de acordo com as normas técnicas, de segurança e preservação ambiental. Sendo assim, ao concluir o curso, o aluno vai adquirir três certificados paralelos sendo:

a) 1a certificação: pesquisar tendência de moda e de mercado para o planejamento e desenvolvimento de coleção, bem como construção dos estilos e sua composição visual;

b) 2a certificação: criar e desenhar esboços, desenhos técnicos, aplicações decorativas e desenvolver produtos;

c) 3a certificação: acompanhar o processo de produção, divulgar produtos da moda e coordenar eventos, todos de acordo com as normas técnicas, de segurança e preservação ambiental.

O Perfil do Curso também destaca a importância em preparar o aluno para os desafios impostos pelo mercado de trabalho e pela sociedade (SENAI, 2008). Dessa forma, o aluno sai com habilidades para atuar como estilista, no mercado de trabalho. Essa atuação pode acontecer tanto na indústria, quanto na abertura de ateliês particulares, partindo da ideia que a busca pelo conhecimento e a pela atualização deverá ser contínua, devido ao mercado estar em constante mudança.

\section{INCLUSÃO SOCIAL NO ENSINO}

Inclusão, do verbo incluir (do latim includere), significa conter em, compreender, fazer parte de, ou participar de. Assim, falar de inclusão no ensino é falar do educando que apresenta deficiência, participando daquilo que o sistema educacional oferece, contribuindo com seu potencial para os projetos e programações das instituições (DICIONÁRIO INFORMAL, [2013]). Pode-se citar como marco importante do ensino inclusivo a Declaração de Salamanca em 1994, na qual foi reafirmado o compromisso com a "Educação para Todos", ficando decidida a inclusão de crianças, jovens e adultos com necessidades educacionais especiais no sistema regular de ensino, devendo a instituição, atender às necessidades de cada um, reconhecendo suas diversidades (BRASIL. Ministério da Educação, [1996]).

Trazendo essa proposta para o ensino técnico e atentando para o fato de realmente se oferecer uma aprendizagem inclusiva em relação aos deficientes visuais, é importante 
que as instituições ofereçam para esses alunos, mecanismos que Ihes possibilitem uma equidade no acesso a recursos técnicos, materiais e humanos, por meio de professores e demais pessoas especializadas, facilitando assim, seu processo de escolarização, e consequente qualificação, tanto para o mundo acadêmico, profissional, quanto para si mesmos.

Mais de 45,6 milhões de brasileiros que representam 23,9\% da população do país declararam ter alguma deficiência, segundo dados do Censo Demográfico 2010, realizado pelo IBGE. A deficiência visual foi a que mais apareceu entre as respostas dos entrevistados e chegou a 35,7 milhões de pessoas, pois $18,8 \%$ dos entrevistados afirmaram ter dificuldade para enxergar, mesmo com óculos ou lentes de contato. Entre as pessoas que declararam ter deficiência visual, mais de 6,5 milhões disseram ter a dificuldade de forma severa, 6 milhões afirmaram que tinham dificuldade de enxergar, e mais de 506 mil informaram serem cegas. (23,9\% Dos Brasileiros..., 2012). Abaixo o gráfico 1 ilustra os tipos e regiões que residem os deficientes no Brasil, segundo o Censo de 2010, divulgado pelo IBGE:

Gráfico 1: Porcentagem Deficiência no Brasil, segundo Censo 2010

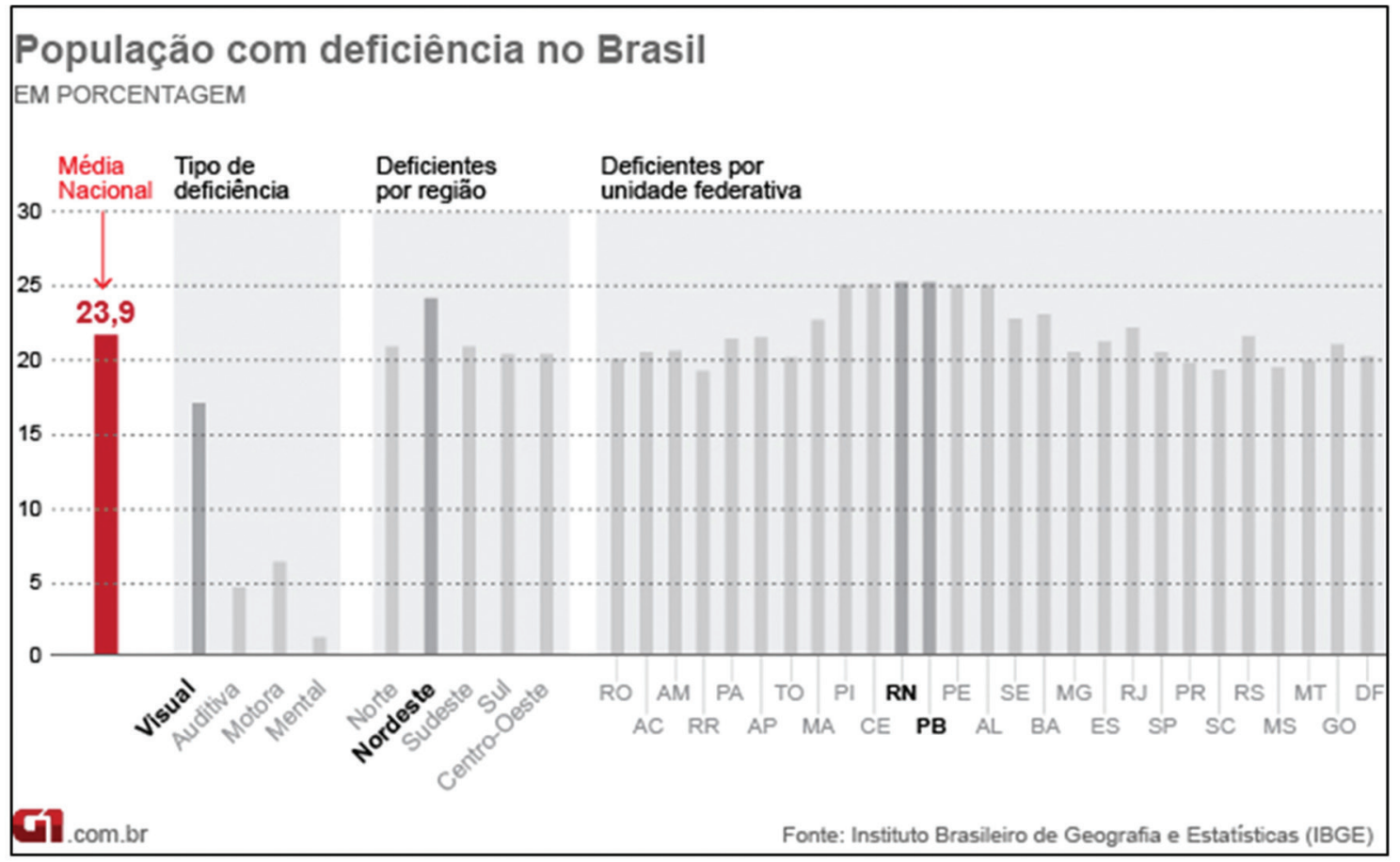

Fonte: IBGE (2010 apud 23,9\% Dos Brasileiros..., 2012) 
O Censo 2010 mostra ainda que existe uma diferença significativa no nível de escolaridade entre pessoas com deficiência e a população geral - $61,1 \%$ da população com 15 anos ou mais com deficiência não têm instrução ou tem apenas o fundamental incompleto. Esse percentual cai 38,2\% para as pessoas sem deficiência. (DRAMAS...,2012).

Ao falar em inclusão, menciona-se a inserção de um indivíduo, que antes estava sendo privado em fazer parte do processo de educação, no qual a instituição deverá estar preparada e apta para atender às deficiências e necessidades desse indivíduo.

O termo inclusão é recente e está em ascensão, antes se abortava o termo integração, no qual o indivíduo que apresentava deficiência teria que se adaptar ao meio em que vivia hoje a sociedade é que deverá respeitar e atender a essas deficiências. Bahia (2006, p. 10) afirma que:

\begin{abstract}
Estamos sob a égide do paradigma de inclusão e não mais da integração. A diferença é que no paradigma da integração, lá pela década de 80 , se dizia que a pessoa com deficiência tinha que se adequar à sociedade em que ela vivia. O problema, então, estava na pessoa, e não na sociedade. A partir dos anos 90, o paradigma da inclusão defende o contrário: que a sociedade deve se preparar para receber a pessoa com deficiência, seja em que campo for.
\end{abstract}

Em relação à ação de ensino inclusivo a instituição SENAI, possui um programa denominado Programa SENAI de Ações Inclusivas (PSAI) desenvolvido em âmbito nacional, que proporciona um ensino profissionalizante para pessoas com deficiências, como também a negros, índios, entre outros, tornando-os preparados e aptos para o mundo do trabalho. Na opinião de Matos (2010, p. 108):

A partir de 1991, com a criação da Lei de Cotas, Lei no 8.213, percebeu-se um movimento muito grande, principalmente por parte das empresas, quanto à busca de pessoas com deficiência, junto às instituições especializadas, para assumirem postos de trabalho em suas instalações. Porém, a partir dessa data, constatou-se que o Brasil não dispõe, em números suficientes, de pessoas com deficiência qualificadas e/ou preparadas para assumirem ocupações no mundo de trabalho, não conseguindo dessa forma, suprir a demanda das empresas. Percebe-se então que se tem uma lacuna entre a necessidade das empresas e a oferta de pessoas com deficiência aptas para assumirem postos no mundo do trabalho.

A demanda das empresas ou o mundo do trabalho precisa de profissionais qualificados, que tenham habilidades para oferecer aos consumidores do mundo da moda, por exemplo, novos e diferentes produtos. 


\subsection{Ação inclusiva no ensino de moda}

A ideia de proporcionar um ensino de moda seguindo um conceito de inclusão social para deficientes visuais, foca numa forma de instruir o educando a fazer uso de suas próprias percepções, sensações e noções durante as aulas.

Com exceção da visualização de imagens e cores, acredita-se que as demais atividades possam ser perfeitamente executadas por alunos com deficiência visual, visto que a moda passou a ser algo que nos proporciona experiências não apenas visuais, mas também táteis e sensoriais.

É essencial manusear os tecidos e testar suas sensações, propriedades e como se comportam quando em contato com o corpo, respeitando caimentos e volumes. 0 tato é estimulado quando sentimos as diferentes texturas que os tecidos possuem e, combinando tecidos diferentes, temos uma habilidade que vale à pena ser acrescentada aos talentos artísticos. Com essa percepção de toques em relação aos materiais aplicados em uma coleção de moda, não somente da imagem que a roupa transmite que surge a ideia central desse trabalho, ou seja, o ensino por meio da unidade curricular Moulage, na qual o aluno iria conceber o modelo a ser criado e, por meio da técnica desenvolvê-lo, desempenhando a função de estilista e modelista.

\subsubsection{Moulage}

A técnica da Moulage do francês "moule" significa forma, e na moda é usado para definir a modelagem tridimencional, ou seja, a modelagem na qual é possível visualizar altura, largura e profundidade e é executada diretamente no corpo ou no manequim devidamente marcado com as medidas necessárias. Consiste na montagem da modelagem através da colocação do tecido sobre o manequim, dando as formas do modelo desejado. Segundo Duburg e Tol (2012, p. 9), "uma técnica artesanal minuciosa de desenvolvimento de peças, que poderia ser chamada de escultura em tecidos, sendo a alma da alta costura".

Por meio da técnica o designer obtém de imediato o resultado de sua criação, assim como, o ajuste da modelagem às curvas do corpo, bem como o efeito do caimento de cada tecido a ser trabalhado. $O$ tecido pode ser moldado justo ao corpo, com caimentos ou volumes longe do corpo, permitindo experimentos e vários testes, resultando trabalhos tanto comerciais, quanto artísticos. Nas figuras 3 e 4 abaixo, pode-se perceber duas vertentes adquiridas por meio da técnica: 


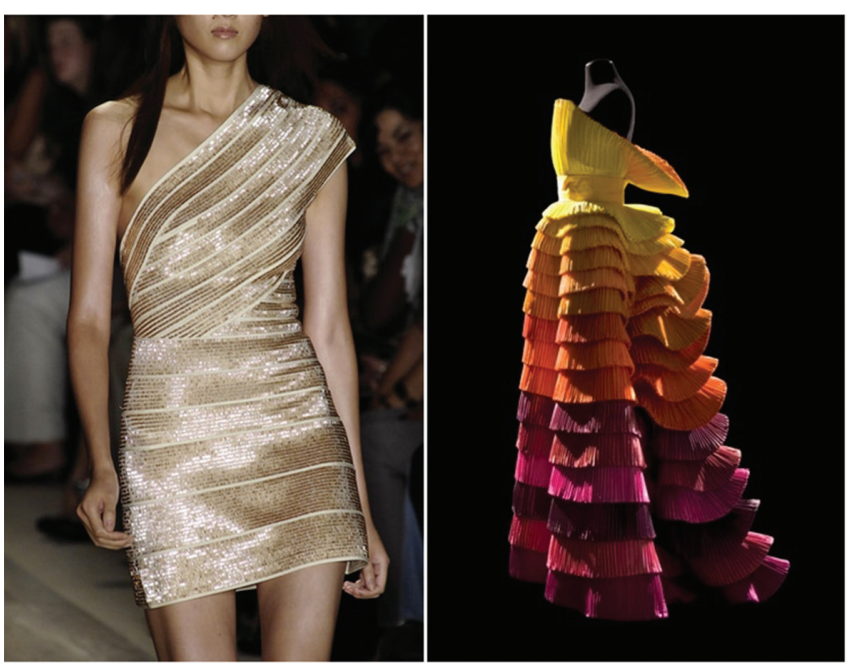

Fonte: Pinterest (2013)

De acordo com Fischer (2010, p. 121), "Madeleine Vionnet (nos anos 20) e Madame Alix Gress (nos anos 30) foram as primeiras estilistas de alta-costura há dedicar seu tempo e talento à arte da Moulage.". Hoje várias marcas resgatam a técnica no desenvolvimento de suas coleções criando produtos com diferencial, principalmente nos trajes de festa, que requerem maior elegância e distinção. As figuras 5 e 6 a seguir, ilustram o trabalho das estilistas citadas acima, além de mostrar o detalhamento que a técnica consegue atingir:

Figuras 5 e 6: Criações de Madeleine Vionnet e de Alix Gress

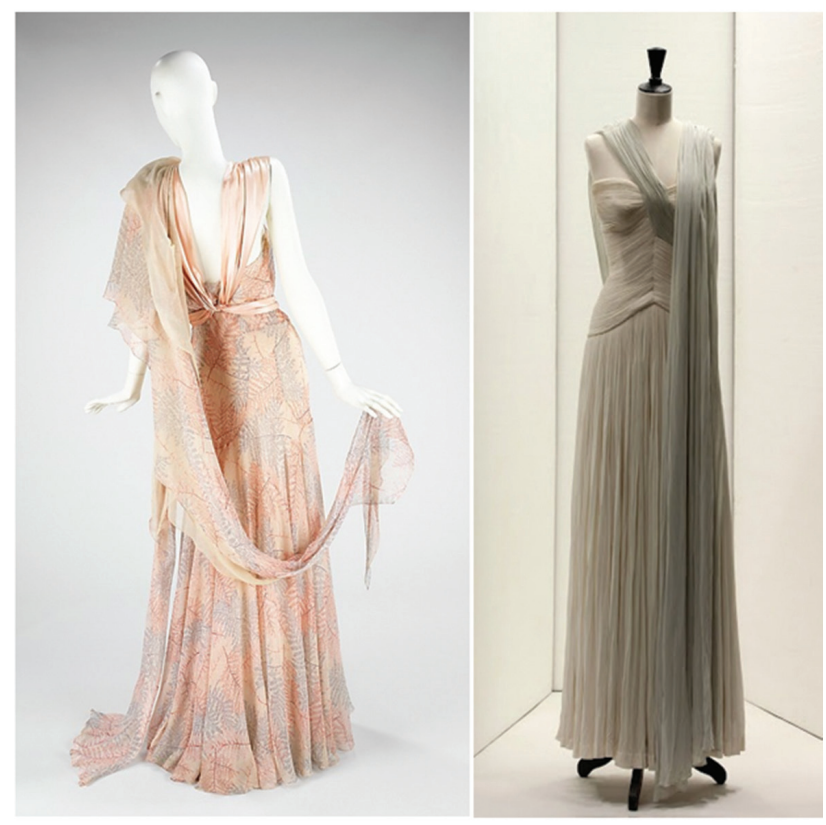

Fonte: Pinterest (2013) 
No entanto, há que se destacar alguns fatores relevantes a serem considerados para contato com a técnica: mão em relação ao toque do designer, o peso e superfície do tecido, para a construção ter em mente o estilo, a proporção e os detalhes desejados, a escolha dos materiais como alfinetes e manequins de tamanhos e formas corretas, enfim, tudo contribui para dar efeito final ao modelo projetado.

Contudo, existem alguns pontos positivos e negativos ao se utilizar a técnica da Moulage:

\section{a) positivos:}

- possibilidade de se ter a peça pronta;

- percentual de erro pequeno;

- liberdade de criação;

- quanto mais se trabalha, mais se adquire experiência;

- possibilidade de se desenvolver modelos diferenciados.

b) negativos:

- utilizar a moulage para desenvolver modelos básicos;

- método um pouco demorado, pois exige muita atenção aos detalhes;

- o manequim não é muito barato;

- somente quando não se sabe fazer uso da técnica.

Abaixo as figuras 7 e 8 mostram os manequins, o primeiro com as marcações necessárias para dar início ao trabalho da Moulage, e o segundo com resultado final do trabalho:

Figura 7 e 8: Manequins com marcações e o resultado final
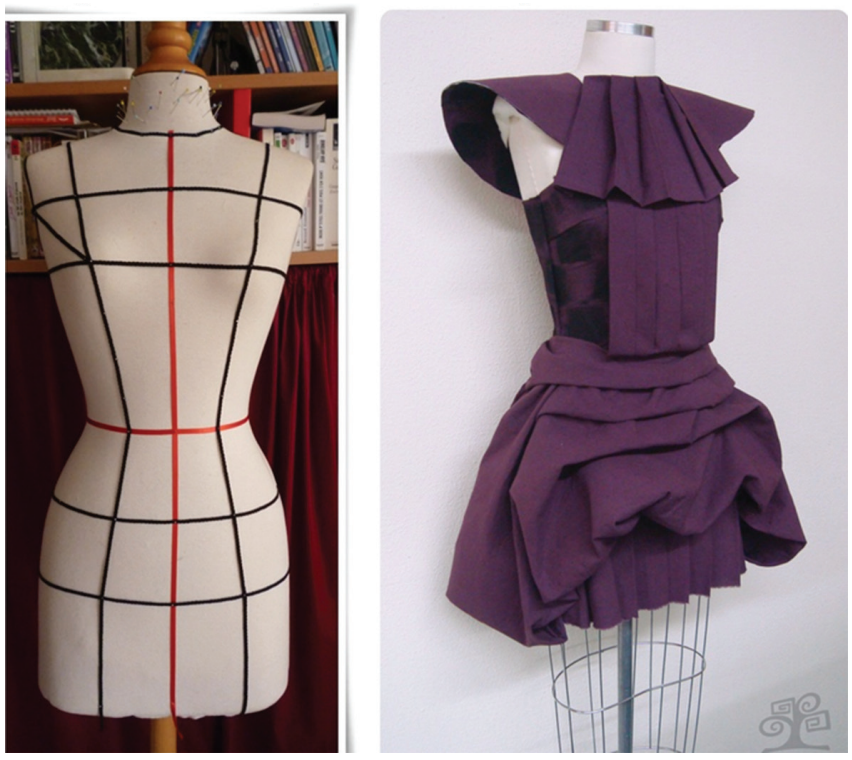

Fonte: Pinterest (2013) 
Como já citado, a técnica pode ser também desenvolvida diretamente no corpo, conforme ilustram as figuras 9 e 10 abaixo:

Figuras 9 e 10: Moulage direto sobre o corpo

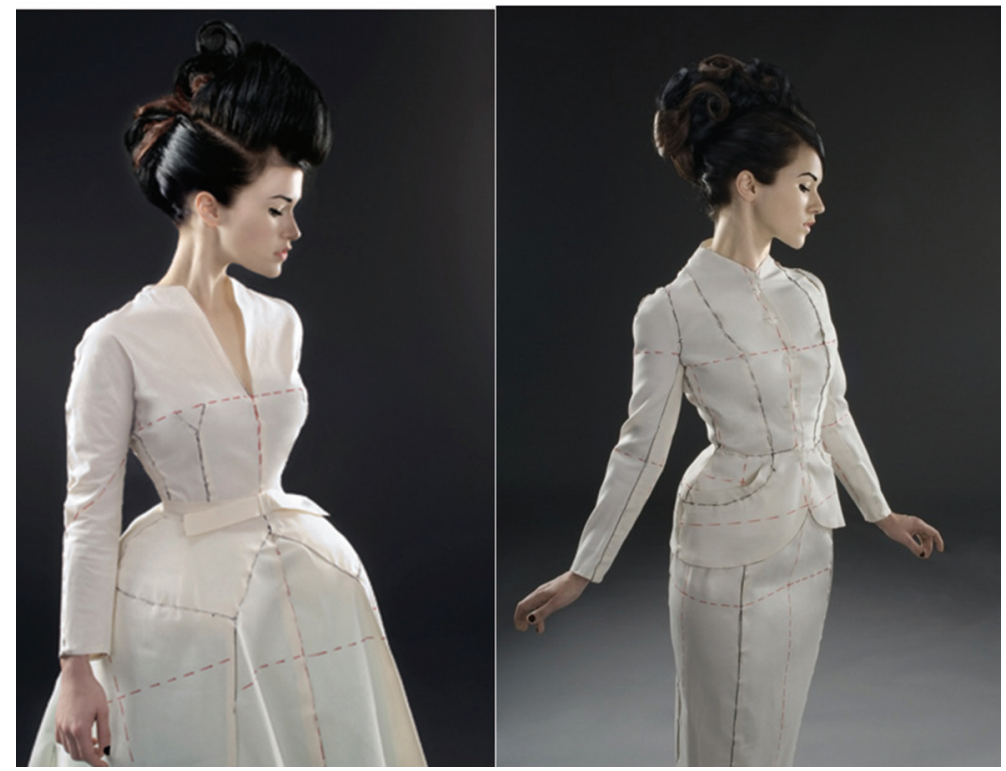

Fonte: Pinterest (2013)

Com relação aos materiais necessários para executar a Moulage seriam: fita métrica, caneta em duas cores para tecidos, papel kraft, tesoura, alfinete, réguas especializadas, tecidos mourin ou algodão mais próximos ao tecido a trabalhar, carretilha, fita, cadarço em duas cores.

A maneira proposta de ensino para essa unidade curricular seria por meio do uso de materiais adaptados, como um manequim projetado com as medidas corretas e possíveis profundidades de cavas, decotes e comprimentos, fitas e canetas com texturas diferenciadas para que fosse possível sentir esta diferenciação através do toque, uma espécie de braile. Seria necessário também um softwear de computador para ajudar nas leituras dos assuntos teóricos, além disso, as criações desenvolvidas pelo aluno, construídas a partir de suas percepções seriam mantidas, tal e qual, porque a ideia de ensino parte do ponto de vista no qual a criatividade sentida e aplicada com a dedicação do aluno e, futuro profissional, deverá ser respeitada e mantida.

Essa proposta de ensino por meio da Moulage estaria inserida dentro de um Curso Profissionalizante Técnico em Produção de Moda, e que conforme já citado, está dividido por módulos, que evoluem com o passar dos semestres. Logo, a unidade curricular Moulage, seria aplicada desde o primeiro até o quarto semestre, existindo o mesmo 
crescimento e progresso cobrado no curso já efetivo. A presente proposta de ensino não descarta a possibilidade dessa unidade curricular, acontecer em paralelo a outras, porém, a maior carga horária seria dedicada a ela.

\title{
4 METODOLOGIA
}

A metodologia de pesquisa utilizada no presente estudo é de abordagem qualitativa, do tipo exploratória.

Os procedimentos metodológicos utilizados foram a pesquisa bibliográfica através de livros e sites com propostas de inclusão social, tanto em meio profissional quanto acadêmico, de conceituação, ensino e mercado de moda e documental diante do Perfil e Conteúdo programático do Curso Técnico em Produção de Moda, oferecido pela instituição de ensino SENAI/SC, na cidade de Blumenau.

Buscou-se também aplicação de um instrumento de pesquisa em forma de questionário contendo perguntas abertas e fechadas, com a intenção de analisar a opinião de pessoas que aplicam e ensinam a técnica de Moulage, perante a proposta de ensino desse estudo.

Segundo Marconi e Lakatos (2010, p. 184):

\begin{abstract}
é um instrumento de coleta de dados, constituído por uma série ordenada de perguntas, que devem ser respondidas por escrito e sem a presença do entrevistador. Em geral, o pesquisador envia o questionário ao informante, pelo correio ou por um portador; depois de preenchido, o pesquisado devolve-o do mesmo modo.
\end{abstract}

O questionário foi enviado via correio eletrônico para seis docentes da unidade curricular proposta, obtendo-se o retorno de cinco, ou seja, 83\% de devolução, e o período de aplicação foi durante o mês de março de 2013.

Além disso, foram realizadas entrevistas informais com os mesmos professores, buscando adquirir informações complementares que viessem a contribuir para o enriquecimento do tema.

A análise desse questionário foi descritiva e interpretativa, com a elaboração de quadros síntese das diversas respostas, buscando fazer reflexões e análises que fossem ao encontro aos objetivos propostos nesse estudo. 


\section{ANÁLISE DOS DADOS}

Após a aplicação e retorno dos questionários, inicia-se a parte de análise dos resultados, que segundo Marconi e Lakatos (2010, p. 09), "analisar significa estudar, decompor, dissecar, dividir, interpretar", tendo em vista identificar as percepções de cada respondente e, assim, chegar às considerações e objetivos propostos.

O questionário aplicado era composto de cinco perguntas, sendo 02 abertas, 02 fechadas e 01 semi-aberta. De acordo com Andrade (2009, p. 136-137):

\section{Perguntas fechadas são aquelas que indicam três ou quatro opções de resposta ou se limitam às respostas afirmativas ou negativas [...] As perguntas abertas dão mais liberdade de resposta, proporcionam maiores informações $[\ldots]$}

Quando questionados sobre quanto tempo tinham contato com a técnica de Moulage, as respostas obtidas variaram de 04 a 15 anos. Percebeu-se que todos possuem experiência com a técnica, pois os mesmos podem afirmar com segurança sobre as facilidades e dificuldades de desenvolver a prática da Moulage, tornando suas contribuições na pesquisa importantes.

Como segunda questão, buscou-se saber há quanto tempo são professores dessa unidade curricular. As respostas variaram 01 a 06 anos de prática atuando com o ensino desta técnica.

Cabe salientar que o presente estudo aborda a proposta da técnica sendo utilizada como instrumento de ensino para deficientes visuais, dessa forma essas respostas são indispensáveis e de importância para o trabalho, visto que as experiências adquiridas em sala de aula permitem maior clareza e definição com relação ao trajeto a ser seguido com a inclusão dos alunos deficientes visuais.

$\mathrm{Na}$ terceira pergunta, buscou-se conhecer as maiores dificuldades dos discentes em aprender essa técnica. De acordo com as respostas, percebeu-se que a dificuldade maior no ensino desta técnica, está na compreensão matemática necessária para a marcação correta do manequim, como também na fusão entre a criatividade e prática da técnica, quando cabe ao aluno gerar a ideia e, em seguida, desenvolver sobre o manequim ou corpo. No quadro 4 abaixo, apresenta-se na íntegra as respostas de cada docente: 
Quadro 4: Respostas da questão 03

\begin{tabular}{|l|l|}
\hline Entrevistado 01 & $\begin{array}{l}\text { "A técnica não apresenta grandes dificuldades. O mais complicado é } \\
\text { fazer o aluno entender que é preciso manter as marcações necessárias } \\
\text { no tecido para o momento de planificação do modelo." }\end{array}$ \\
"A técnica pode ser dividida em duas categorias: a) essencialmente \\
criativa, com uma exploração livre da técnica sobre o manequim, porém \\
gera dificuldades no momento em tornar a criação bidimensionalo ou \\
b) essencialmente técnica, tem dificuldades em relação a criatividade, \\
porém possui conhecimento de costura e modelagem plana, o que \\
facilita no momento de planificação. \\
Sendo assim a técnica exige tanto o conhecimento técnico, quando o \\
uso da criatividade. "O que percebo é que a técnica é vendida como \\
sendo o resultado para todos os problemas, mas quando o aluno \\
percebe que tem que transformar tudo aquilo que ele idealizou no \\
manequim em 'molde', ele se desespera." \\
"Não vejo muita dificuldade no aprendizado da técnica, os alunos \\
normalmente gostam muito, a única parte que é um pouco mais \\
complicada é a marcação do manequim." \\
"A maior dificuldade é na marcação do manequim, acredito que \\
seja devido aos cálculos matemáticos que são utilizados. Os demais \\
conteúdos fluem normalmente." \\
"Compreensão de costura, tecidos, modelos."
\end{tabular}

Fonte: Dos autores (2013)

Ao serem questionados sobre se já tiveram algum aluno em sala de aula que apresentava deficiência visual, apenas 01 (um) docente respondeu já ter tido aluno que apresentava essa deficiência, os demais responderam negativamente.

Assim, este docente respondeu as perguntas complementares que seriam: Caso afirmativo, quais foram as dificuldades/facilidades no aprendizado dessa técnica, por parte dos alunos? E quais os resultados obtidos por esses alunos, em relação aos demais? De acordo com o docente, o aluno deficiente visual teve dificuldade no início dos estudos, porém, esse professor foi desenvolvendo a técnica com paciência, mostrando como era tranquila, até que o educando fosse criando gosto pela técnica e conseguindo desenvolvê-la a cada aula com mais prazer e facilidade.

Aos demais professores que não tiveram alunos com deficiência visual em sala, perguntouse se consideravam que um aluno com deficiência visual teria como desenvolver habilidades práticas para a aplicação desta técnica e por quê. O resultado geral foi que os 
professores acreditam nesse formato de ensino, diante da sensibilidade em relação ao tato aguçado dos alunos, por outro lado, citaram como dificuldade, o desenvolvimento de modelos mais elaborados, pois não teriam como visualizar caimentos e recortes desejados.

Outro ponto a ser considerado foi o fato de o aluno ficar comprometido em relação à interpretação de croquis de outros estilistas, mas conforme citado por um dos professores entrevistados: "O problema está resolvido caso ele seja o criador e tenha uma modelista a seu dispor para finalizar o trabalho através da planificação.". No entanto, o estudo tem como proposta a ideia do aluno criar e desenvolver o produto, assim, ele poderia sentir as formas e curvas do corpo, bem como seguiria uma proposta de temática, para a qual desenvolveria o produto utilizando a técnica apresentada. Abaixo o quadro $5 \mathrm{com}$ as respostas do professores:

Quadro 5: Respostas da questão 04

\begin{tabular}{|c|c|}
\hline $\begin{array}{l}\text { Entrevistado } 01 \text { - } \\
\text { Negativo }\end{array}$ & $\begin{array}{l}\text { "Sim e não, porque para fazer corpinhos básicos com a técnica, o que precisa } \\
\text { ter de mais aguçado é o tato, pois precisamos deixar o tecido ajustado ao } \\
\text { corpo (manequim) então, nesse caso, alunos que tenham deficiência visual } \\
\text { conseguem executar a atividade. Mas para modelos mais elaborados, onde } \\
\text { tem que se ver o caimento do tecido para definir um recorte, acredito que } \\
\text { dificulta para estes alunos." }\end{array}$ \\
\hline $\begin{array}{l}\text { Entrevistado } 02- \\
\text { Negativo }\end{array}$ & $\begin{array}{l}\text { "No processo tradicional, a primeira complicação seria a interpretação de um } \\
\text { modelo desenvolvido por um estilista através de um croqui, por exemplo. Ele } \\
\text { até poderia trabalhar a tela no manequim porque seria tranquilo ele identificar } \\
\text { as partes do corpo através do tato, porém, a interpretação e planificação do } \\
\text { produto ficariam comprometidas. O problema está resolvido caso ele seja o } \\
\text { criador e tenha uma modelista a seu dispor para finalizar o trabalho através } \\
\text { da planificação." }\end{array}$ \\
\hline $\begin{array}{l}\text { Entrevistado } 03- \\
\text { Negativo }\end{array}$ & $\begin{array}{l}\text { "Acredito que a técnica ajudaria muito o aluno com deficiência visual, pois } \\
\text { permite que o mesmo faça uso do tato, que é um sentido bem aguçado nestas } \\
\text { pessoas." }\end{array}$ \\
\hline $\begin{array}{l}\text { Questionado } 04 \\
\text { - Negativo }\end{array}$ & $\begin{array}{l}\text { "Sim. Acredito que é possível, pois o deficiente visual possui muita sensibilidade } \\
\text { no tato e conseguirá através do mesmo realizar a moulage das peças." }\end{array}$ \\
\hline $\begin{array}{l}\text { Entrevistado } 05- \\
\text { Afirmativo }\end{array}$ & $\begin{array}{l}\text { "No começo tem bastante dificuldade, mas logo as facilidades e habilidades } \\
\text { começam a surgir e todo dia o gosto pela matéria aumenta, onde que no final } \\
\text { o aluno adora a técnica. Basta ter paciência com eles e mostrar com facilidade } \\
\text { as técnicas." }\end{array}$ \\
\hline
\end{tabular}

Fonte: Dos autores (2013) 
Na quinta e última pergunta, abordou-se sobre os métodos de ensino necessários para que esses alunos desenvolvam a prática da técnica de Moulage. Assim, a partir das respostas acreditou-se ser possível seguir a mesma, o que seria desenvolvido seria o material em braile, produzindo uma série de trabalhos práticos a fim de explorar a criatividade, além de preparar exercícios em relação às texturas de diferentes tecidos e proporções de diversos modelos, bem como proporcionar conhecimento do corpo humano por meio do toque, aplicar conceitos de ergonomia e antropometria. Todos estes aspectos acrescidos da "disposição incessante do professor em querer dar o máximo para fazer o aluno aprender", conforme ressaltado por um dos professores entrevistados. No quadro 6 seguem as respostas obtidas:

Quadro 6: Respostas da questão 05

\begin{tabular}{|l|l|}
\hline Entrevistado 01 & $\begin{array}{l}\text { "Não podemos dizer que é impossível um aluno com deficiência visual } \\
\text { aprender a técnica, pois hoje vemos cada exemplo de superação que } \\
\text { é inacreditável. Acredito que se o aluno quer mesmo aprender e tem } \\
\text { um bom tato e o professor se disponibilizar a realmente dar o máximo } \\
\text { para fazer o aluno aprender, creio que o resultado será incrível. Força } \\
\text { de vontade e superação é tudo." } \\
\text { "Acredito que a criatividade seja um dos métodos para trabalhar } \\
\text { a técnica da moulage com esses alunos. Passando é lógico, por uma } \\
\text { intensa preparação desse aluno no conhecimento do corpo humano } \\
\text { através da ergonomia e antropometria. Esse aluno poderia trabalhar } \\
\text { essa criatividade na produção de vitrines, exposições e tantas outras } \\
\text { possibilidades que o mercado tem oferecido atualmente como também } \\
\text { ser o criador e inovador na possibilidade de criações." } \\
\text { "Instruções das técnicas em Braile; Trabalhos práticos para o } \\
\text { desenvolvimento do tato." } \\
\text { "Utilizar a mesma metodologia que o utilizamos para o vidente, porém } \\
\text { o material deverá ser em braile e quando for informatizado dispor de } \\
\text { telas de leituras para cegos." } \\
\text { "Ter e saber modelagem, saber um pouco de costura, saber noção de } \\
\text { modelos, saber aproveitar os alunos." }\end{array}$ \\
\hline Entrevistado 05 03
\end{tabular}

Fonte: Dos autores (2013)

Assim, após o levantamento de dados e ao referencial pesquisado, pôde-se constatar a viabilidade no ensino de moda para deficientes visuais, mediante o desenvolvimento da técnica de Moulage e de adaptações nos materiais e recursos didáticos. 


\section{CONSIDERAÇÕES FINAIS}

O conceito de moda, já não é mais o mesmo que em tempos atrás, pois ao longo do tempo, sofreu alterações passando a ser uma forma de marcar uma época e as pessoas que fazem parte dela.

Somente a aparência que a roupa tem já não é mais suficiente, é necessário sentir a roupa, por meio do toque, pelo seu caimento, e que essa roupa vista um corpo muito bem.

Além disso, tornou-se um mercado em crescimento contínuo que necessita cada vez mais de profissionais capacitados para atender toda uma demanda de novos produtos. Partindo dessa ideia, acredita-se na viabilidade da proposta desenvolvida nesse estudo, transmitindo uma nova concepção no ensino da moda, para pessoas que querem trabalhar nessa área, porém, que possuam alguma deficiência visual.

Devido ao aumento no número de pessoas que afirmaram possuir algum tipo de deficiências segundo as pesquisas realizadas pelo IBGE nos últimos anos, gerou uma preocupação em disponibilizar formas de estudos para que os mesmos tenham acesso a cursos profissionalizantes.

Pode-se dizer que essas pessoas também buscam dar continuidade a seus estudos, aperfeiçoando-se. Desta forma, o ensino inclusivo tem acompanhado essa evolução, sendo necessário que as instituições de ensino se adaptem para atender a esses novos consumidores.

Assim, diante dos resultados apresentados, a proposta de ensino seria viável, mas os alunos teriam dificuldades em iniciar o trabalho com a técnica em relação à marcação de manequins e a junção da criatividade com a prática desse método, porém, essas dificuldades já existem em sua aplicação habitual, também se destacou alguns pontos que merecem atenção, como o fato de que talvez o aluno tenha dificuldade em desenvolver algo muito elaborado, ou então, em não conseguir compreender croquis de outros estilistas. Entretanto, conforme já mencionado, o aluno desempenhará tanto a função de criador da ideia (estilista) quanto de produtor (modelista), obtidos, essencialmente, por meio da técnica de ensino proposta.

Como não foi realizado nenhum experimento prático com esses deficientes, acreditase que a princípio o mesmo teria somente condições de realizar trabalhos artísticos indiferentes se direto ao corpo ou sobre um manequim, mas algo exclusivo para alguns clientes durante ocasiões específicas, como uma festa ou casamento.

Assim, este estudo não se esgota aqui, torna-se necessário o desenvolvimento de novas pesquisas, bem como realizar experimentos nos quais esse aluno poderia ser colocado frente a um manequim e realizar alguma criação e, por meio desses testes, identificar com mais particularidade qual seria de fato o foco do trabalho a ser seguido pelo aluno, bem como as adaptações necessárias para que a técnica de Moulage seja aplicada. Desta forma, considera-se que os objetivos idealizados no seu início em propor o ensino de moda para deficientes visuais foram alcançados. 


\title{
THE TEACHING OF FASHION AND THE INCLUSION OF VISUALLY IMPAIRED
}

\begin{abstract}
The teaching of fashion is mainly marked by the development of projects of collections, in which the student will get in touch with the cycles that products go through understanding the concept of fashion as a way to introduce yourself to others in regards to physical appearance. It is guided by the change, the ephemeral, by the many innovations with each new season, affecting a huge market, because the clothes, before they reach the consumer, go through a cycle, which goes from the processing of raw materials, to the catwalks and stores, constituting itself as a huge market, which drives the economy and creates jobs. Thus, this study aims to examine the possibility of inclusion of persons with visual impairment in the Course of Vocational Technician in Fashion Production, at Senai Blumenau, Santa Catarina, because, among the most cited deficiencies in recent years cited by the IBGE surveys in 2010, visual deficiency corresponded to $18.8 \%$ of respondents. Due to the fact that inclusive education aims at the inclusion of an individual, who was previously excluded from being part of the education process, becoming part of it. Therefore, it is suggested in this paper to study the inclusion of visually impaired people in fashion education, through the curricular unit of Draping. The research methodology used was qualitative, exploratory, through bibliographic procedures, documentary and questionnaires with teachers who apply this technique. The result was positive, with some recommendations to be considered in relation to the methodology and materials needed, proposing practical experiences in order to enrich and give continuity to this study.
\end{abstract}

Keywords: Fashion. Education. Draping. Inclusion. Visual Impairment.

\section{REFERÊNCIAS}

ANDRADE, Maria Margarida de. Introdução à metodologia do trabalho científico: elaboração de trabalhos na graduação. 9. ed. São Paulo: Atlas, 2009.

BAHIA, Melissa. Responsabilidade social e diversidade nas organizações: contratando pessoas com deficiência. Rio de Janeiro: Qualitymark, 2006. 
BARROS, Michele. Mercado de moda faturou R\$ 130 bilhões no ano passado: setor é um dos que mais cresceram no Brasil e está fazendo muita gente buscar a formação acadêmica. [2012]. Disponível em: <http://g1.globo.com/jornal-da-globo/ noticia/2012/06/mercado-de-moda-faturou-r-130-bilhoes-no-ano-assado.html>. Acesso em: 17 jan. 2013.

BRAGA, João. História da moda: uma narrativa. 9. ed. São Paulo: Anhembi Morumbi, 2011.

BRASIL. Ministério da cultura. Moda. 16 maio 2008. Disponível em: <http://www2. cultura.gov.br/site/pnc/diagnosticos-e-desafios/manifestacoes-culturais/moda/>. Acesso em: 17 jan. 2013.

BRASIL. Ministério da educação. Declaração de Salamanca. [1996]. Disponível em: $<$ http://portal.mec.gov.br/seesp/arquivos/pdf/salamanca.pdf>. Acesso em: 16 fev. 2013.

COBRA, Marcos. Marketing e moda. São Paulo: Senac São Paulo: Cobra Editora \& Marketing, 2007.

DESIGN BRASIL. O mercado de moda. [2013]. Disponível em: <http://www.designbrasil. org.br/setoresprodutivos/moda-e-vestuario/o-mercado-de-moda>. Acesso em: 17 jan. 2013.

DICIONÁRIO INFORMAL. Inclusão. [2013]. Disponível em: <http://www. dicionarioinformal.com.br/inclusao>. Acesso em: 03 abr. 2013.

DRAMAS cercam deficientes, que são $24 \%$ da população. 0 Estado de São Paulo, São Paulo, 30 jun. 2012. Disponível em: <http://www.estadao.com.br/noticias/ impresso,dramas-cercam-deficientes-que-sao-24-da-populacao-,893774,0.htm>. Acesso em: 16 fev. 2013.

DUBURG, Annette; TOL, Rix van der. Moulage: arte e técnica no design de moda. Tradução: Bruna Pacheco. Porto Alegre: Bookman, 2012.

FISCHER, Anette. Fundamentos de design de moda: construção de vestuário. Tradução: Camilla Bisol Brum Scherer. Porto Alegre: Bookman, 2010. 
JONES, Sue Jenkyn. Fashion design: manual do estilista. Tradução: lara Biderman. São Paulo: Cosac Naify, 2005.

LIPOVETSKY, Gilles. O império do efêmero: a moda e seu destino nas sociedades modernas. São Paulo: Cia das Letras, 1989.

LUCENA, Patrícia. Mercado da moda se profissionaliza e vira opção de carreira: variedade de opções de trabalho é uma das vantagens da profissão. iG São Paulo, 28 jan. 2011. Disponível em: <http://economia.ig.com.br/carreiras/mercado-da-moda-seprofissionaliza-e-vira-opcao-de-carreira/n1237971422526.html>. Acesso em: 17 jan. 2013.

MARCONI, Marina de Andrade; LAKATOS, Eva Maria. Fundamentos de metodologia cientifica. 7. ed. São Paulo: Atlas, 2010.

MATOS, Osvair Almeida. A inclusão da pessoa com deficiência no mercado de trabalho: um olhar sob a perspectiva da educação profissional. In: MANICA, Loni Elisete et.al.

Ações inclusivas na educação profissional do SENAI. Brasília: SENAI, DN, 2010. Cap. 6, p. $101-112$.

PALOMINO, Erika. A moda. 2. ed. São Paulo: Publifolha, 2003.

PINTEREST. 2013. Disponível em: <www.pinterest.com>. Acesso em: 19 jan. 2013.

RENFREW, Elinor; RENFREW, Colin. Desenvolvendo uma coleção. Tradução: Daniela Fetzner; revisão técnica: Camilla Bisol Brum Scherer. Porto Alegre: Bookman, 2010.

SERVIÇO NACIONAL DE APRENDIZAGEM INDUSTRIAL. Departamento Regional de Santa Catarina. Perfil profissional do curso de produção de moda. 2008. Disponível em: <https://www.sc.senai.br/intranet>. Acesso em: 19 jan. 2013.. Acesso Restrito.

Departamento Regional de Santa Catarina. Técnico em Produção de Moda. Blumenau: SENAI/SC, 2013. Disponível em: <http://www.sc.senai.br>. Acesso em: 19 jan. 2013.. Acesso Restrito.

TREPTOW, Doris. Inventando moda: planejamento de coleção. 4. ed. Brusque:

D.Treptow, 2007. 
VAI Brasil!: São Paulo e Rio de Janeiro estão entre as cidades mais importantes da moda. Portal fashion forward, Rio de Janeiro,13 set. 2012. Disponível em: <http:// ffw.com.br/noticias/moda/sao-paulo-e-rio-de-janeiro-estao-entre-as-cidades-maisimportantes-da-moda/>. Acesso em: 17 jan. 2013.

23,9\% DOS BRASILEIROS declaram ter alguma deficiência, diz IBGE. PORTAL G1: Brasil: Notícias, 27 abr., 2012. Disponível em: <http://g1.globo.com/brasil/ noticia/2012/04/239-dos-brasileiros-declaram-ter-alguma-deficiencia-diz-ibge.html>. Acesso em: 16 fev. 2013.

\section{APÊNDICE A}

Para melhor desenvolvimento da pesquisa proposta, foi aplicado um questionário com os professores do SENAI - Blumenau que lecionam a Unidade Curricular de Moulage. Segue abaixo o questionário desenvolvido:

\section{QUESTIONÁRIO}

Eu, Cristiani Maximiliano, regularmente matriculada no Curso Moda: Criação, Desenvolvimento e Comunicação da Universidade do Vale do Itajaí, solicito sua colaboração no preenchimento da pesquisa com o título: "Proposta de Ensino de Moda para Deficientes Visuais, através da Técnica de Moulage."

Os dados serão utilizados somente para a realização da pesquisa e elaboração de um artigo científico, para a diplomação no referido curso, sob a orientação da Professora Simone Batista Tomasulo MSc.

Estas informações esclarecem que você está ciente que esta pesquisa será desenvolvida por meio de um questionário abaixo, com perguntas fechadas e abertas e que esta pesquisa garantirá o sigilo e anonimato de todos os participantes.

Pelo fato desta pesquisa ter única e exclusivamente interesse científico, por ser voluntária e sem interesse financeiro, não será feita nenhuma remuneração. A divulgação do resultado total dos dados coletados visará apenas mostrar os possíveis benefícios obtidos pela pesquisa em questão, sendo que você poderá solicitar informações durante todas as suas fases, inclusive após a publicação da mesma.

Cidade, XX de Março de 2013.

Assinatura 
1) Quanto tempo tem contato com a técnica?

2) Há quanto tempo é professor dessa unidade curricular?

3) Quais são as maiores dificuldades dos discentes em aprender essa Técnica?

4) Você já teve algum aluno em sala de aula que apresentava deficiência visual?

( ) $\operatorname{Sim}($ ) Não

Caso afirmativo, quais foram as dificuldades/facilidades no aprendizado dessa técnica, por parte dos alunos? Quais foram os resultados obtidos por esses alunos, considerando os demais?

Caso negativo, você considera que um aluno com deficiência visual teria como desenvolver habilidades práticas para o desenvolvimento desta técnica? Por quê?

5) Quais métodos de ensino, você acredita serem necessários para que esses alunos desenvolvam a prática da técnica de Moulage? 


\section{SOBRE OS AUTORES}

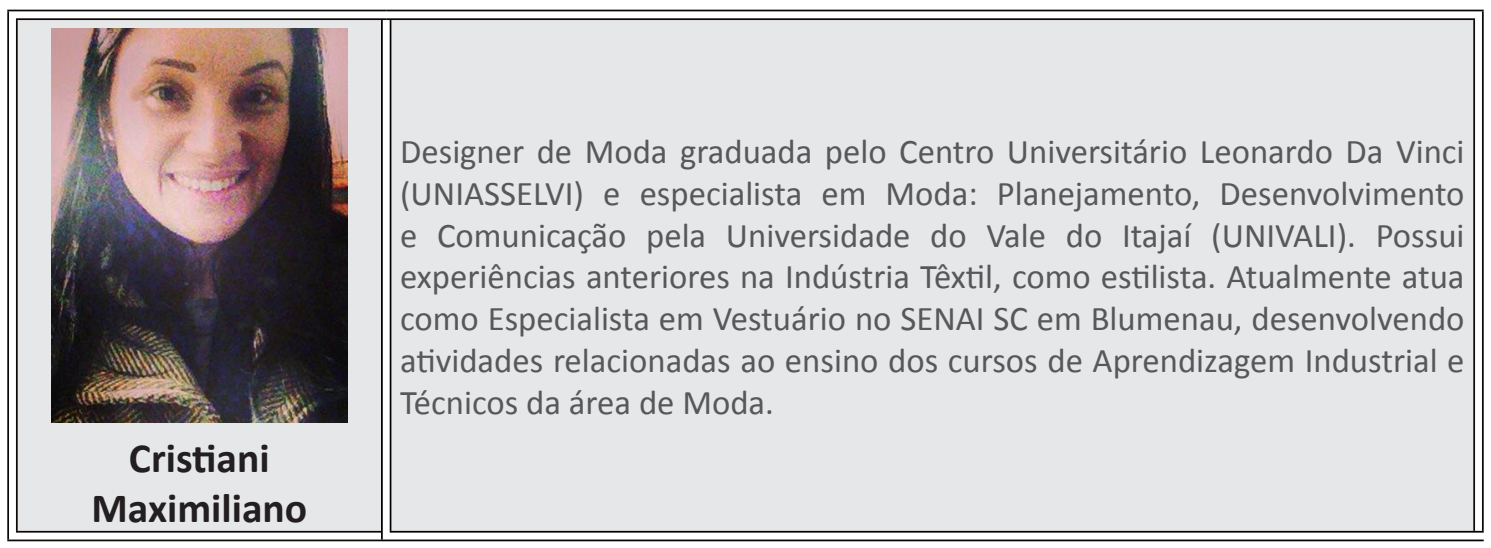

\begin{tabular}{|c|c|}
\hline $\begin{array}{c}\text { Simone Batista } \\
\text { Tomasulo }\end{array}$ & $\begin{array}{l}\text { Graduada em Turismo pela Universidade Federal do Paraná (1988) e } \\
\text { Mestre em Turismo e Hotelaria pela Universidade do Vale do Itajaí (2002) } \\
\text { oHá quinze anos atua como docente na Universidade do Vale do Itajaí em } \\
\text { cursos de graduação como Turismo e Hotelaria, Design de Interiores, Moda e } \\
\text { Industrial, Estética, Administração e, na pós-graduação lato sensu nas áreas } \\
\text { de Turismo e Hotelaria (no qual também coordenou alguns cursos), Docência } \\
\text { no Ensino Superior, Enogastronomia, Moda, Ambientação de Interiores, } \\
\text { Marketing e Serviços. Tem experiência na área de Turismo, trabalhando de } \\
1990 \text { a } 1998 \text { no mercado de São Paulo e em } 2008 \text { participou de um trabalho } \\
\text { de consultoria tendo em vista elaborar um diagnóstico para implantação de } \\
\text { roteiros enoturísticos em Santa Catarina. }\end{array}$ \\
\hline
\end{tabular}

Originais recebidos em: 30/08/2013

Texto aprovado em: 15/10/2013 